\title{
A New Spider Species, Xysticus metinaktasi n. sp. from Turkey (Araneae, Thomisidae)
}

\author{
Demir, H.; Seyyar, O. ; Türker, H. \\ Department of Biology, Faculty of Science and Arts, Niğde Ömer Halisdemir University, Niğde, Turkey \\ *Corresponding Author: Seyyar, O, Department of Biology, Faculty of Science and Arts, Niğde Ömer \\ Halisdemir University, Niğde, Turkey
}

\begin{abstract}
Xysticus metinaktasi $n$. sp. is described and illustrated based on female specimens collected from inner western Anatolian region of Turkey.
\end{abstract}

Keywords: Spider, Xysticus metinaktasi, new species, Turkey.

\section{INTRODUCTION}

Xysticus is a genus of ground crab spiders described by C. L. Koch in 1835, with the type species $X$. audax (Schrank, 1803). The genus is represented by approximately 372 species and subspecies worldwide. So far, 48 species of the crab spider genus of Xysticus have been recorded from Turkey [1, 2].

In this paper, the new species Xysticus metinaktasi n. sp. from inner western Anatolia region of Turkey is described.

\section{Materials ANd Methods}

All samples were collected in Inner Western Anatolia of Turkey by hand collecting. Illustrations of the female genitalia were made with a Nikon SMZ-U stereomicroscope with drawing tube. Abbreviations: ap, apical; d, dorsal; p, prolateral; ALE, anterior lateral eyes; AME, anterior median eyes; PLE, posterior lateral eyes; PME, posterior median eyes; MOA, median ocular area; MOA-L, length of MOA; MOA-WA, anterior width of MOA; MOA-WP, posterior width of MOA; $r$, retrolateral; v, ventral; All material is deposited in the Arachnology Museum of the Niğde Ömer Halisdemir University, Niğde, Turkey (NOHUAM). Terminology and system of leg spination follow Ono [3]. All measurements are in millimeters.

\section{RESULTS AND DISCUSSION}

\section{Xysticus metinaktasi sp. nov.}

Material. Holotype. 19 (OHUAM) Uşak province, Banaz District, near the Yeşilyurt 1012m, 02.VI.2015 (29 $\left.43^{\prime} \mathrm{E} 38^{\circ} 47^{\prime} \mathrm{N}\right)$, leg. H. Demir. Paratypes: 19 (NOHUAM) Afyonkarahisar province, Sultandağı district $1122 \mathrm{~m}, 29 . \mathrm{V} .2015\left(31^{\circ} 12^{\prime} \mathrm{E} 38^{\circ} 31^{\prime} \mathrm{N}\right)$, leg. H. Demir; 1 + (NOHUAM) Şuhut district, Başören village 1539m, 26.VI.2015 (30² $\left.25^{\prime} \mathrm{E} 38^{\circ} 28^{\prime} \mathrm{N}\right)$ leg. O. Seyyar.

Female. Measurements (holotype + ). Carapace: 5.00 long, 5.50 wide. Chelicera 1.80 long, clypeus 0.50 long. Abdomen: 8.20 long, 6.80 wide. Eye sizes and inter distances: AME 0.10, ALE 0.40, PME 0.10, PLE 0.20, AME-AME 0.90, AME-ALE 0.60, MOA-WA 0.20, MOA-WP 0.20, MOA-L 0.25, PME-PME 1.10, PME-PLE 1.00.

Table 1. Leg measurements of Xysticus metinaktasi n. sp. from Turkey

\begin{tabular}{|c|c|c|c|c|c|c|}
\hline & Femur & Patella & Tibia & Metatarsus & Tarsus & Total \\
\hline I & 4.00 & 2.80 & 3.50 & 2.00 & 1.00 & 13.30 \\
\hline II & 4.50 & 2.80 & 3.50 & 2.00 & 1.10 & 13.90 \\
\hline III & 2.70 & 1.40 & 2.00 & 2.20 & 1.20 & 9.50 \\
\hline IV & 2.40 & 1.90 & 2.50 & 1.90 & 1.10 & 9.80 \\
\hline
\end{tabular}


Carapace light-brown with V-shaped cream median band and eyes tubercles yellow. Maxillae, sternum and labium yellowish. Chelicerae light brown. Legs yellow with brown dots and stripes.

Table 2. Leg spination of Xysticus metinaktasi $\mathrm{n}$. sp. from Turkey

\begin{tabular}{|l|c|c|c|c|}
\hline & $\mathrm{d}$ & $\mathrm{v}$ & $\mathrm{p}$ & $\mathrm{r}$ \\
\hline Femur & $1-1-1$ & - & - & - \\
\hline Tibia & - & $0-2-2-2 \mathrm{ap}$ & - & - \\
\hline Metatarsus & - & $2-2-2-2 \mathrm{ap}$ & $0-1-1$ & $0-1-1$ \\
\hline
\end{tabular}

Dorsum of abdomen brown, folium yellow; venter of abdomen light brown. Spinnerets light brown, branchial opercula yellowish.

Epigyne. Epigynal plate centrum slants gradually towards epigastric furrow; distinct sclerotised heartshaped rims enclose central part on each side with two dark spots severally on median corners. Elevated sclerotised rims with two dark rings separately on lower corners. Spermathecae reniform and long. Spermathecal structures show no variation (Figs. 1-4).

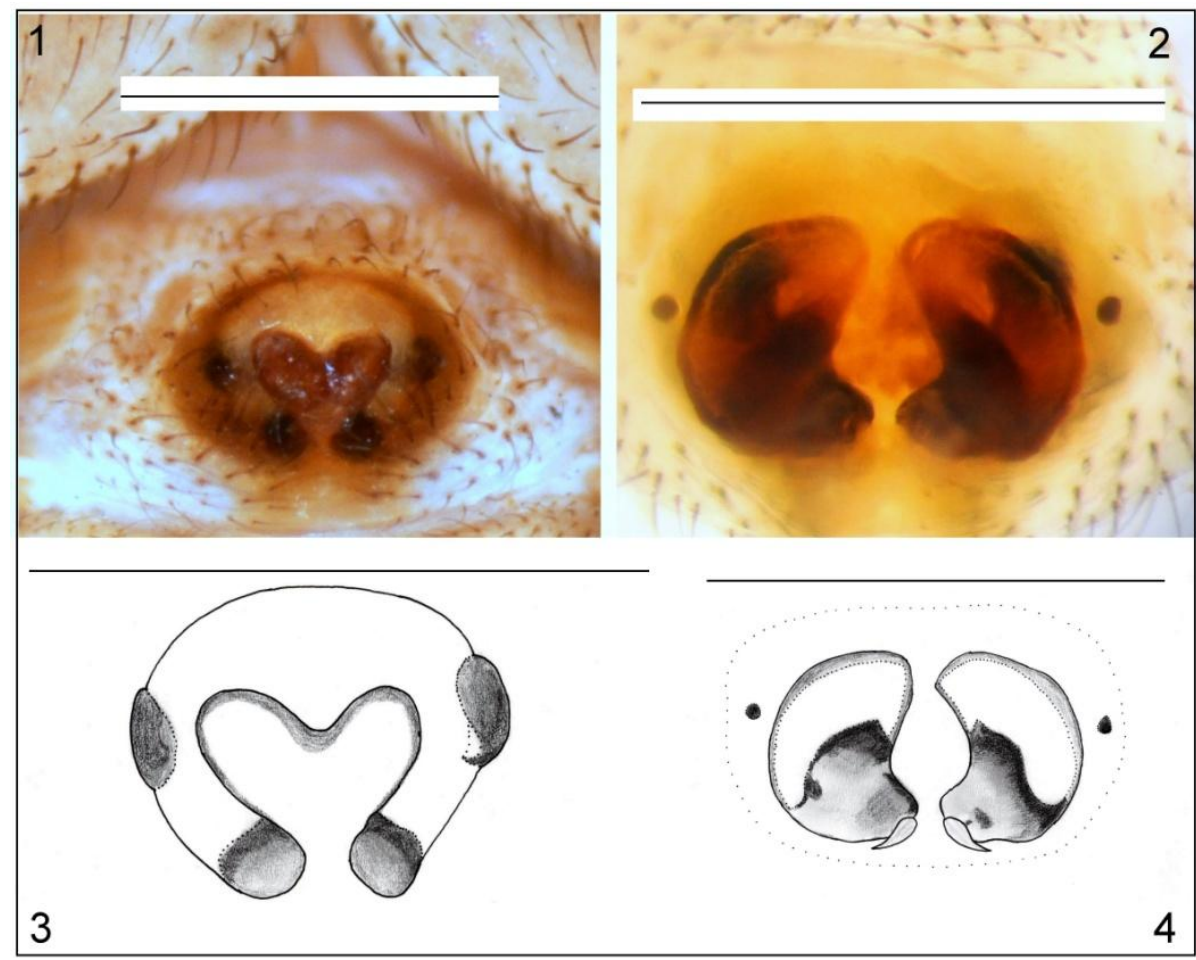

Figures. 1-4. Female genitalia of Xysticus metinaktasi n. sp. 1, 3. Epigyne, 2, 4. Vulva. Scale bars $=0.1 \mathrm{~mm}$.

Diagnosis. The females of Xysticus metinaktasi n. sp. are similar to X. cor Canestrini, 1873 (cf. Thaler and Noflatscher [4]: figs. 44-45 and Demir et. al., 2010a: fig. 5) and $X$. atevs Ovtsharenko, 1979 (cf. Ovtsharenko [5]: fig 5), but can be separated from these species by the sclerotised heartshaped rims of epigynum with two dark spots on median corners, and shape of its spermathecae.

Male. Unknown.

Distribution. Turkey.

Etymology. The new species is named to the fond memories of Prof. Dr. Metin Aktaş, who passed away in 2012.

Habitat. Found under stone, in grass vegetation.

Nomenclatural acts. This work and the nomenclatural acts it contains have been registered in ZooBank. The ZooBank Life Science Identifier (LSID) for this publication is: http://zoobank. org/urn:lsid:zoobank.org:pub: 43709145-426F-4522-BC0C-1CF0F9EE345D.

\section{ACKNOWLEDGMENTS}

This study was supported by the Scientific and Technological Research Council of Turkey (TUBITAK) (Project No. 214Z016). 


\section{REFERENCES}

[1] Demir H. and Seyyar O., Annotated checklist of the spiders of Turkey. Munis Entomology \& Zoology 12 (2), 433-469 (2017).

[2] Platnick, N.I., World Spider Catalog. Natural History Museum Bern, online at http://wsc.nmbe.ch, version 18.5 [accessed 28 September 2017].

[3] Ono H., A revisional study of the spider family Thomisidae (Arachnida, Aranei) of Japan. National Science Museum, Tokyo, 252 pp. (1988)

[4] Thaler K. and Noflatscher M.T., Neue und bemerkenswerte Spinnenfunde in Südtirol (Arachnida: Aranei). Veröff Mus Ferdinandeum 69, 169-190 (1990).

[5] Ovtsharenko V.I., Spiders of the families Gnaphosidae, Thomisidae, Lycosidae (Aranei) in the Great Caucasus. Trudy Zool Inst Leningrad 85, 39-53 (1979).

Citation: H. Demir et al., " A New Spider Species, Xysticus metinaktasi n. sp. from Turkey (Araneae, Thomisidae) ", International Journal of Research Studies in Zoology, vol. 3, no. 3, p. 20-22, 2017. http://dx.doi.org/10.20431/2454-941X.0303003

Copyright: (C) 2017 Authors. This is an open-access article distributed under the terms of the Creative Commons Attribution License, which permits unrestricted use, distribution, and reproduction in any medium, provided the original author and source are credited. 